\title{
Angelo Poliziano and the graphetai Symbol in His Notes on Catullus
}

\author{
GIOVANNI GRANDI
}

This paper focuses on a small group of variant readings written down by Angelo Poliziano in his copy of the editio princeps of Catullus, now Roma, Biblioteca

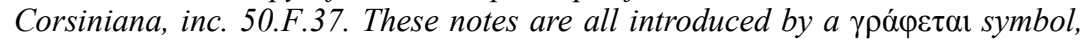
which has not been taken into account by scholars so far and which, despite its ambiguity, could attest to manuscript collations. Many of these variant readings are similar to the ones recorded by Francesco Buzzacarini in his copy of Catullus, now Venezia, Biblioteca Nazionale Marciana, ms. lat. XII.153 (4053). This, along with the fact that Giorgio Merula mentions Buzzacarini as one of the scholars from whom Poliziano allegedly "stole" his emendations, is used as the basis for formulating new hypotheses concerning these variants."

Angelo Poliziano's annotated incunables are one of the greatest pieces of evidence of his approach towards the emendation of classical texts, as they still carry the traces of his careful collations with other manuscripts. ${ }^{1}$ Sometimes Poliziano owned more than one printed copy of the same text, each one attesting a different collation, and other times it is even possible to compare such collations with their reference manuscript. For example, two of his copies of Terence are still available today: the first one has been collated with the famous Codex Bembinus (now Città del Vaticano, Biblioteca Apostolica Vaticana, ms. Vat. lat.

* I would like to thank the anonymous referees and the editorial staff of Humanistica Lovaniensia for their invaluable feedback, as well as all the people that helped me during the drafting and revision of this note: Damiano Acciarino, Alex Agnesini, Maria Chiara Alessandrini, Stefano Cianciosi, Amelia Goonerage, Maxine Lewis, Tim Markey, and Will Theiss.

${ }^{1}$ A. Daneloni, "Angelo Poliziano (Angelo Ambrogini)", in F. Bausi, M. Campanelli, S. Gentile (ed.), Autografi dei letterati italiani. Il Quattrocento, vol. 1 (Roma, 2013), 305312; F. Lo Monaco, "Apografi di postillati del Poliziano. Vicende e fruizioni”, in V. Fera, G. Ferraù, S. Rizzo (ed.), Talking to the Text. Marginalia from Papyri to Print, vol. 2 (Messina, 2002), 615-648. Poliziano's textual criticism is an extremely vast topic, on which see especially I. Maïer, Ange Politien. La formation d'un poète humaniste, 14691480 (Genève, 1966); S. Rizzo, Il lessico filologico degli umanisti (Roma, 1973), 162165; A. Grafton, "On the Scholarship of Politian and Its Context", Journal of the Warburg and Courtauld Institutes 40 (1977), 150-188; L. Silvano (ed.), A. Poliziano, Appunti per un corso sull'Odissea. Editio princeps dal Par. gr. 3069 (Alessandria, 2010). 
3266); ${ }^{2}$ the other one carries the traces of a collation with a different manuscript, which Poliziano labels with a Greek-fashioned symbol, identified by Lucia Cesarini Martinelli as Firenze, Biblioteca Medicea Laurenziana, ms. Plut. 38.24. ${ }^{3}$

However, we are often confronted with more complex situations, and this is the case with his notes on the 1472 editio princeps of Catullus, now Roma, Biblioteca Corsiniana, inc. 50.F.37, an edition containing Catullus, Tibullus, Propertius and Statius' Sylvae. ${ }^{4}$ Catullus' text was highly corrupt at that time, and Poliziano gave an account of his emendations in two subscriptions. The first one, dated 1473 and placed at the end of Catullus, quite boastfully informs the reader that he, an eighteenyear-old scholar, was able to emend Catullus by comparing "numerous texts of this poet" and "many Greek and Latin authors"; the subscription to Propertius, written in 1485, partially resizes the impact of such claims, inviting the reader not to use those notes "to form an opinion or judgement of [his] intellect", as many of them "deserve to be erased". ${ }^{5}$

The first note suggests that he had ambitious projects for his Catullan emendations, or "the edition that might have been", as Julia Gaisser named it; ${ }^{6}$ however, soon after August 1473, the second, improved edition of Catullus was printed in Parma, and then five more editions were subsequently printed before 1485 . It is likely, then, that Poliziano abandoned the project of his own printed edition, or perhaps commentary,

2 The edition is a copy of Publius Terentius Afer, Comoediae. Vita Terentii ([Venezia, Adam de Ambergau?], 1475 [USTC 990585]), now Firenze, Biblioteca Nazionale Centrale, inc. B.R. 97; see R. Ribuoli, La collazione polizianea del codice Bembino di Terenzio. Con le postille inedite del Poliziano e le note su Pietro Bembo (Roma, 1981).

3 This is a copy of Publius Terentius Afer, Comoediae. Vita Terentii ([Napoli], Printer of Terence, [1470] [USTC 990599]), now Firenze, Biblioteca Medicea Laurenziana, inc. D’Elci 194; see L. Cesarini Martinelli, "Uno sconosciuto incunabolo di Terenzio postillato dal Poliziano", Rinascimento 25 (1985), 239-246.

${ }^{4}$ It was printed in Venice by Vindelinus de Spira [USTC 990388]. On this specific incunable see I. Maïer, Les manuscrits d'Ange Politien (Genève, 1965), 361-362; Ead. 1966 (as in n. 1), 116-129; Rizzo 1973 (as in n. 1), 155-164; J.H. Gaisser, "Catullus and His First Interpreters: Antonius Parthenius and Angelo Poliziano", Transactions of the American Philological Association 112 (1982), 83-106; Ead., "Catullus, Gaius Valerius", in V. Brown, P.O. Kristeller, F.E. Cranz (ed.), Catalogus translationum et commentariorum. Mediaeval and Renaissance Latin Translations and Commentaries (Washington, DC, 1992), 197-292, at 230-231; Ead., Catullus and His Renaissance Readers (Oxford, 1993); H.M. Dixon, “Angelo Poliziano's Unpublished Notes on Tibullus in Roma, Corsiniana, 50 F 37”, Medioevo e rinascimento 20 (2006), 245-286.

${ }^{5} \mathrm{I}$ am quoting the English translation by Gaisser 1993 (as in n. 4), 43-44.

${ }^{6}$ Gaisser 1993 (as in n. 4), 42, as previously suggested by Maïer 1966 (as in n. 1). 
and such a decision could be attested by the different self-judgement in the aforementioned subscription to Propertius. However, Gaisser suggests that he kept working on Catullus even after the first subscription, according to the different inks, handwritings and relative note position in the margins; ${ }^{7}$ she then argues that Poliziano's original project had given way to some selected explanations of Catullan problems in his Miscellanea. ${ }^{8}$ We also know from archival records that he probably owned another incunable of Catullus, which unfortunately has been lost. ${ }^{9}$

Poliziano is generally regarded as responsible for some of the major improvements of the otherwise wildly corrupt text of Catullus; both the readings discussed in the Miscellanea and the ones witnessed by the Corsiniana incunable have been thoroughly studied by Julia Gaisser. ${ }^{10}$ Even though she limits her survey to only the "successful" emendations (that is to say, she leaves out all the other readings, labelled as "wrong emendations" and "restoration[s] of the archetype"), Gaisser points out that some of those improvements could have been already available in manuscripts and printed sources during Poliziano's alleged working period (at least 1473-1485); she thus classifies the emendations according to the latest available printed witness, even if they were previously circulating in manuscripts, and finally concludes that, given the high amount of interpolation among Catullan manuscripts, the identification of Poliziano's sources is far from possible.

${ }^{7}$ Gaisser 1993 (as in n. 4), 43; Ead. 1982 (as in n. 4), 86. On Poliziano's handwriting see P. Supino, "La scrittura di Angelo Poliziano", in V. Fera, M. Martelli (ed.), Agnolo Poliziano. Poeta, scrittore, filologo. Atti del convegno internazionale di studi, Montepulciano, 3-6 novembre 1994 (Firenze, 1998), 225-244.

8 Angeli Politiani Miscellaneorum centuria prima (Firenze, Antonio di Bartolommeo Miscomini, 1489 [USTC 991839]). The Catullan loci examined in Poliziano's Miscellanea are Cat. 98.4 (Misc. 2); Cat. 2 (Misc. 6); Cat. 84 (Misc. 19); Cat. 66.48 (Misc. 68); Cat. 66.94 (Misc. 69); Cat. 17.19 (Misc. 83); see Gaisser 1982 (as in n. 4), 94-106; Ead. 1993 (as in n. 4), 67-78. He quotes Catullus (29.5) only once in his second, unpublished Centuria (4.14); see V. Branca, M. Pastore Stocchi (ed.), A. Poliziano, Miscellaneorum centuria secunda, editio minor (Firenze, 1978 [anastatic reprint of the introduction and the critical text of the 1972 editio princeps, with corrections]), 10.

${ }^{9}$ G. Bombieri, "Un secondo incunabulo di Catullo postillato dal Poliziano?", Scripta philologa 2 (1980), 7-16; M. Rossi, "Catulliana", in L. Bertolini, D. Coppini, C. Marsico (ed.), Nel cantiere degli umanisti. Per Mariangela Regoliosi (Firenze, 2014), 1083-1097.

${ }^{10}$ See n. 8. For the readings not witnessed by the Miscellanea see Gaisser 1982 (as in n. 4), 86-94; Ead. 1993 (as in n. 4), 45-47 and Appendix 3, 403-407. 
While agreeing with Gaisser's conclusion, I would like to highlight a detail that has not been taken into account by scholars in order to suggest possible new directions for further studies on these variant readings; namely, a symbol (traced with overlapping $\gamma \rho$ ) that Poliziano uses to introduce roughly seventy of them, sometimes single letters above the line, other times complete verses (see Appendix for a survey of the variants I have read and transcribed). ${ }^{11}$ Such a symbol is very common in Greek and Byzantine manuscripts, where it stands for $\gamma \rho \alpha \dot{\varphi} \varepsilon \varepsilon \alpha 1$, "it is written", meaning that the variant is not conjectural, but taken from another witness. ${ }^{12}$ Nigel Wilson has recently pointed out that sometimes it might indeed stand for $\gamma \rho \alpha \dot{\alpha} \varphi \varepsilon$ or $\gamma \rho \alpha \pi \tau \varepsilon$ cov, therefore introducing a conjecture by the scribe; such cases, however, are limited to a small number, and they are often quite recent and/or with a fairly narrow manuscript tradition. ${ }^{13}$

It is known that Poliziano began to study Greek in Florence early in his adolescence, so that he was already able to translate Homer's Iliad around 1470:14 it is very likely, then, that he learned this symbol from the Greek manuscripts he was reading and studying (for instance, it can be found in his copy of the scholia in Aratus, now Firenze, Biblioteca Medicea Laurenziana, ms. Plut. 28.37, f. 25r). ${ }^{15}$

$\Gamma \rho$ does not seem to be used very often by Poliziano, and therefore I do not think it could be possible precisely to define whether in the author's mind it stood for $\gamma \rho \alpha \dot{\varphi} \varphi \varepsilon \tau \alpha$ or $\gamma \rho \alpha \dot{\varphi} \varphi \varepsilon / \gamma \rho \alpha \pi \tau \varepsilon \dot{o v}$. It appears four times to introduce variant readings in his commentary on Ovid's Fasti: it is worth mentioning that in this case it is used only in the citations from Greek authors, and it is compared by Francesco Lo Monaco to other symbols he uses to introduce Latin variant readings such as c' for

${ }^{11}$ None of these readings happen to be discussed in the Miscellanea: see above, n. 8 .

12 On such use in Renaissance Italy, specifically by Marsilio Ficino, see D. Robichaud, "Working with Plotinus. A Study of Marsilio Ficino's Textual and Divinatory Philology", in F. Ciccolella, L. Silvano (ed.), Teachers, Students, and Schools of Greek in the Renaissance (Leiden - Boston, MA, 2017), 120-154, at 127.

13 N.G. Wilson, "An Ambiguous Compendium", Studi italiani di filologia classica 20 (2002), 242-243; Id., "More About $\gamma \rho \alpha ́ \varphi \varepsilon \tau \alpha 1$ Variants", Acta Antiqua Academiae Scientiarum Hungaricae 48 (2008), 79-81.

14 J. Irmscher, "Poliziano come grecista", in L. Rotondi Secchi Tarugi (ed.), Poliziano nel suo tempo. Atti del VI Convegno internazionale (Chianciano - Montepulciano, 18-21 luglio 1994) (Firenze, 1996), 195-199.

15 The manuscripts' digital reproductions can be viewed at mss.bmlonline.it. 
credo (on which see below). ${ }^{16}$ There are, however, three other clues that seem to lean towards the meaning of $\gamma \rho \alpha \dot{\varphi} \varphi \varepsilon \tau \alpha$.

First: in his incunable of Quintilian's Institutio oratoria (now Firenze, Biblioteca Nazionale Centrale, inc. Banco Rari 379) he writes several marginal notes, such as emendations, parallel passages, diagrams, presumably dated $1480-1481 .{ }^{17}$ At f. $18 \mathrm{v}$ he first fills in the blank space

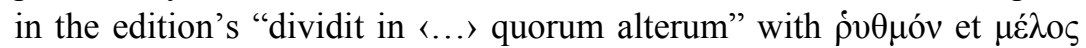

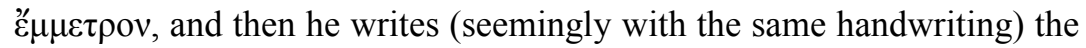
variant reading $\mu \varepsilon \varepsilon \tau \rho o v$. He seems to use the $\gamma \rho$ symbol twice, above $\stackrel{\varepsilon}{\varepsilon} \mu \mu \varepsilon \tau \rho o v$ (body of text) and $\mu \varepsilon \dot{\tau} \rho \circ$ (margin): given that both readings are witnessed by two Quintilian manuscripts used by Poliziano to emend his edition, it is likely that he meant to use this symbol to mark an actual collation. $^{18}$

Second: at Cat. 113.2, on the Corsiniana incunable, Poliziano writes, beside the printed "Mecillia", the note " $\gamma \rho$ Mechidia c' $\mu \eta \chi i\langle\lambda \lambda \iota "$ " [sic, see Plate 1]. The c' symbol, as mentioned above, is generally interpreted as credo in Poliziano's marginal notes, as if it introduces a conjecture, but it can often suit other purposes, such as the suggestion of other variant readings, peculiar etymologies, translations of Greek words or the tentative identification of the author of certain quotations. ${ }^{19}$ Here at Cat. 113.2, then, $\gamma \rho$ and c' might indeed imply different meanings, rather than the same but for different languages, as in Lo Monaco's edition mentioned above: the former may thus be a neutral report ("so it is written"), while the latter may imply some further degree of reasoning ("I think"). ${ }^{20}$

16 F. Lo Monaco (ed.), A. Poliziano, Commento inedito ai Fasti di Ovidio (Firenze, 1991), XXX, 207 (1. 25), 376 (1. 50), 400 (1. 40), 418 (1. 355).

${ }^{17}$ A. Daneloni, Poliziano e il testo dell 'Institutio oratoria (Messina, 2001), 35.

18 Daneloni 2001 (as in n. 17), 125. "E $\mu \mu \varepsilon \tau \rho \circ v$ is witnessed by Firenze, Biblioteca Medicea Laurenziana, ms. Plut. 46.7, and $\mu \varepsilon \dot{\tau} \rho \circ$ vy Milano, Biblioteca Ambrosiana, ms. F 111 sup. The incunable's complete digital reproduction can be accessed through the Autografi dei letterati italiani database at www.autografi.net.

19 All of these instances can be found in Silvano 2010 (as in n. 1), 40 (1. 45), 43 (1. 19), 69 (1. 14), 99 (1. 44). On the interpretation of this symbol see Rizzo 1973 (as in n. 1), 272274; L. Cesarini Martinelli (ed.), A. Poliziano, Commento inedito alle Selve di Stazio (Firenze, 1978), XII, n. 11; Daneloni 2001 (as in n. 17), 151, with further bibliography. See also Lo Monaco 1991 (as in n. 16), 543, for a detailed index of the instances of credo in Poliziano's commentary on Ovid's Fasti.

${ }^{20} \mathrm{M} \eta \chi \dot{i} \lambda \lambda 1 \alpha$, which has not been found in Catullus manuscripts so far, could be a tentative Greek transcription of the name Maechilia, possibly made by Poliziano himself. On this verse see also A. Agnesini, "Una possibile rilettura dei carmi 113 e 94 di Catullo. Sulle tracce di un ciclo di Mucia", Exemplaria classica 16 (2012), 45-73. 
Third: certain variant readings are marked by Poliziano with a cross sign (see Appendix and Plate 2). He does not always use this symbol with the same meaning, but generally speaking it is used to mark dubious or uncertain variant readings. ${ }^{21}$ If they were conjectural, it would be quite hard to explain such confusing behaviour. (However, it is also true that he explicitly and dramatically changed his opinion about some of his emendations in 1485 , as discussed above, so this might still be an example of such self-corrections.)

Furthermore, some $\gamma \rho$ variants are not written in full, but with only one or two letters above the line (Plate $3,1.2$ ). This practice is highly common in medieval Greek manuscripts, but the act of marking a single letter with a symbol, even in the narrow space between two lines, may suggest that Poliziano somehow needed to set it apart from other corrections similarly made. This, together with the three aforementioned clues, may imply that such a distinction could be made on the basis of a manuscript collation.

After collecting all the " $\gamma \rho$ readings", I noticed that they seem to share a similar handwriting, more cursive and mature than other notes, and in some cases their relative disposition suggests that they were written at a later stage (see for instance the note at Cat. 17.3, f. 8r - Plate 4). Another interesting feature emerged after a comparison with the online repertoire of Catullan humanistic conjectures available on Dániel Kiss's Catullus Online first, and then with selected manuscripts not yet completely recognized by Kiss. The first, broad comparison highlighted predictable similarities with editions and manuscripts dated up to the 1480 s, especially with the edition of Giovanni Calfurnio, printed in Verona in 1481 by Johannes de Reno and Dionysius Bertochus [USTC 996174] (23 variants out of 71); the second, more focused examination outlined an exact match of 58 variants with the emendations made by the Paduan humanist Francesco Buzzacarini (ca. 1440-1500) in his copy of

21 The cross sign clearly marks the wrong reading "desertae" for "secretae" when Poliziano quotes Verg. Aen. 5.613 in his commentary on Homer's Odyssey; see Silvano 2010 (as in n. 1), 21 (1.33). However, it does not seem to have the same meaning on page 57 (1. 50), where it is placed above $\delta \chi \chi \theta \dot{\alpha}$, the correct (but rare) reading of Hom. Od. 1.23. On this topic see also V. Fera, Una ignota Expositio Suetonii del Poliziano (Messina, 1983), 37-38, 235; Ribuoli 1981 (as in n. 2), 25-28; Daneloni 2001 (as in n. 17), 138-142. 
Catullus, now Venezia, Biblioteca Nazionale Marciana, ms. lat. XII.153 (4053). ${ }^{22}$ This manuscript also contains Tibullus, and the two authors were probably copied in Padua at different times, around the late 1450s, by the famous scribe Bartolomeo Sanvito; only the text of Catullus, however, was thoroughly annotated by Buzzacarini, apparently in several stages.

It has been suggested that the core of Buzzacarini's notes could derive from a collation with a lost manuscript with a peculiar poem division, which he carefully reports along with the marginalia: such an order and such notes are partly witnessed by other manuscripts, now London, British Library, ms. Burney 133 (probably dated before 1471), London, British Library, ms. Egerton 3027 (dated 1467) and Pesaro, Biblioteca Oliveriana, ms. 1167 (dated 1470). ${ }^{23}$ It is likely, then, that Buzzacarini expanded this core with either his own notes and emendations, or those from other sources, even printed commentaries, but this second phase is harder to demonstrate. There is, however, some weak proof ex silentio that can make the hypothesis of Buzzacarini's acquaintance with printed editions and commentaries less likely, such as the missing division of poem 24 (available since the editio princeps) and the awkward and unsuccessful explanation of poem 63's metre, which is correctly

22 On this manuscript see A.C. de la Mare, L. Nuvoloni, Bartolomeo Sanvito. The Life and Work of a Renaissance Scribe (Paris, 2009), 122. On Buzzacarini see G. Ballistreri, "Buzzacarini, Francesco", in Dizionario biografico degli Italiani, vol. 15 (Roma, 1972), 641-642, with further bibliography, and E. Martellozzo Forin, Flessibilità medioevale. I cartolai padovani nel secolo dell'invenzione della stampa, vol. 2 (Padova, 2016), 15-17.

23 See M. Zicàri, "Ricerche sulla tradizione manoscritta di Catullo", Bollettino per l'edizione nazionale dei classici, n.s., 6 (1958), 77-99, at 84-85, reprinted in Id., Scritti Catulliani (Urbino, 1978), 79-108, at 86. On ms. Burney 133, which originally was a single piece with the current ms. Burney 343, containing Giovanni Pontano's Parthenopeus, see A. Iacono, "Il manoscritto Burney 343 della British Library di Londra nella tradizione manoscritta del Parthenopeus di G. Pontano", in M. Santoro (ed.), Le carte aragonesi. Atti del convegno. Ravello, 3-4 ottobre 2002 (Pisa - Roma, 2004), 283296, and G. Grandi, "An Hypothesis Regarding the Scribe of London, British Library Burney 133 and 343", Paideia 71 (2016), 647-660. On Egerton 3027 see A. Palmer, R. Ellis, "Scaliger's Liber Cujacianus of Propertius, Catullus etc.", Hermathena 2 (1876), 124-158; A.T. Grafton, "Joseph Scaliger's Edition of Catullus (1577) and the Traditions of Textual Criticism in the Renaissance", Journal of the Warburg and Courtauld Institutes 38 (1975), 155-181, at 161. On ms. Oliv. 1147 see M. Zicàri, "Il codice pesarese di Catullo", Storia oliveriana 1 (1953), 5-23, reprinted in Zicàri 1978 (as in this note), 4360. On all the three manuscripts within the Catullan tradition see D.F.S. Thomson (ed.), Catullus (Toronto - Buffalo, NY, 1997), at 78 and 83. 
described as galliambic already in Partenio's first commentary, published in $1485 . .^{24}$

There are indeed some more similarities between Buzzacarini's and Poliziano's annotations, such as quotations of classic authors. However, the $\gamma \rho$ variants are by far the most striking match, especially given that at least one of them, from what is known to date, only appears in those two annotated copies of Catullus (8.9 "tuque impote non es", see Appendix).

Some of those readings could have been independently conjectured by the two scholars, such as 4.6 "hadriatici" (the editio princeps reads "hadriaci" and Sanvito's text "adriatici"), but some other variants are far too elaborate to argue an independent origin. Such is the case with 61.180 "at virum iuvenem tamen" (Buzzacarini reads "ad"), both replacing "ad maritum tamen iuvenem": such a reading, which is not otherwise witnessed, implies a substitution of "virum" with "maritum" (perhaps a gloss, penetrated into the text?) and an inversion.

Given that Poliziano's and Buzzacarini's lives partially overlapped, one may ask what kind of relationship, if any, might exist between the two groups of variants. Before any further speculation, a detail about Buzzacarini's scholarly work should be clarified; that is, the period of his annotations on Catullus. Although there is no date, nor any possible clear termini, I think that two elements could help at least to narrow the time frame. The first one is a manuscript of Pomponius Mela (Modena, Biblioteca Estense Universitaria, ms. lat. 950), entirely written by Buzzacarini, and then collated and annotated with methods and inks very similar to the ones that can be seen in his Catullus. ${ }^{25}$ The subscription dates it to 1467. Given that Buzzacarini quotes Pomponius Mela in the margins of Catullus, as well as Catullus in Pomponius Mela, it is likely that, by that date, he was already acquainted with both texts.

Another element that must be taken into account comes from a humanist of the same period, Giorgio Merula, who, in his unpublished and spiteful opuscule against Poliziano's Miscellanea, presumably

${ }^{24}$ Antonii Parthenii Lacisii Veronensis in Catullum commentationes (Brescia, Boninus de Boninis, 1485 [USTC 996173]).

${ }^{25}$ De la Mare, Nuvoloni 2009 (as in n. 22), 399, n. 10; G. Grandi, "Il manoscritto estense $\alpha$ K.6.15. Postille (petrarchesche?) a Pomponio Mela e revisioni di Francesco Buzzacarini”, Paideia 72 (2017), 595-610. 
written soon after their publication (1489), claims that many of Poliziano's emendations are actually "thefts" from previous scholars' works. ${ }^{26}$ Buzzacarini is mentioned by Merula four times, one of which refers to his explanation of Cat. 66. 94 "Oarion" on the basis of a verse

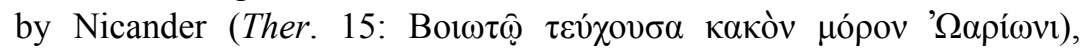
which, according to Merula, predates chapter 69 of Poliziano's Miscellanea by almost 25 years: ${ }^{27}$

Francesco Buzzacarini, a man quite interested in the study of Greek and Latin, if he is right in explaining any obscure passage of Catullus and in emending any verse (even if anything spurious had to be deleted), showed me very virtuously, almost twenty-five years ago in Padua, that one should read "Oarion" [Cat. 66.94], after a comparison with a verse by Nicander [Nic. Ther. 15.19]. Probably, if I am not mistaken, you [Poliziano] may have learned such things from him.

This is quite a clear and explicit statement for the hateful and often vague Merula, ${ }^{28}$ and it seems to have quite solid foundations when compared to Buzzacarini's manuscript, which carries the very verse of Nicander at 66.94 (Venezia, Biblioteca Nazionale Marciana, ms. lat. XII.153 (4053), f. 101r), after several uncertain attempts of emendation (see Plate 5). If we assume that Merula wrote his opuscule around 14891490 , and if we assume that his date for Buzzacarini's work is trustworthy, it gets extremely close to what can be inferred from the cross references between Catullus and the aforementioned Pomponius Mela; that is to say that he was probably working on his manuscript around the

\footnotetext{
26 On such dating see G. Morelli, "Per la cronologia degli Adnotamenta del Merula ai Miscellanea del Poliziano", Studi e problemi di critica testuale 60 (2000), 21-49. On the opuscule see L. Perotto Sali, "L'opuscolo inedito di Giorgio Merula contro i Miscellanea di Angelo Poliziano", Interpres 1 (1978), 146-183; R. Fabbri, "La inedita epistola di dedica del Merula al suo In Politianum e una notizia sulla tradizione di Seneca Retore", Atti della Accademia Nazionale dei Lincei, Rendiconti. Classe di Scienze morali, storiche e filologiche, 34 (1979), 291-296; Ead., "Per la polemica Poliziano-Merula", in Fera, Martelli 1998 (as in n. 7), 551-556; Fera, "Il dibattito umanistico sui Miscellanea", in Fera, Martelli 1998 (as in n. 7), 333-364.

27 Text from Perotto Sali 1978 (as in n. 26), 127: "Oarion sinceriter atque pure legi oportere Franciscus Buzacharinus, Graecae et Latinae observationis non incuriosus, siquid ad Catulli obscuros sensus explicandos, castigandos versus, vel siquid subdititii fuit expungendum, facit, circiter quinque et viginti abhinc annos Patavii, collatis Nicandri carminibus, mihi ostendit. Abs quo, si non male coniecto, forsan haec didicisti."

${ }^{28}$ See note 26 and also M. Santoro, "La polemica Poliziano-Merula", Giornale Italiano di Filologia 5 (1952), 212-233.
} 
mid-1460s. However, there is still no clue as to the precise period in which he ceased to annotate it.

With the small amount of data available I do not think that a single, unambiguous explanation for such affinities is possible. However, while hoping that further research will help in answering this open question, I will try to suggest three possible scenarios, along with their advantages and disadvantages.

a. Buzzacarini copied Poliziano's notes, or one of their descendants. This suggestion is plausible, because we know that Poliziano visited the Veneto twice, in $1479-1480$ and in $1491 . .^{29}$ During the former visit he had the chance to give some informal lectures, the most famous of which is the interpretation of Catullus given to a small crowd, gathered in a shop to avoid the falling rain in Verona, described by Poliziano himself in Misc. 1.19 to prove the age of his emendations of poem $84 .{ }^{30}$ However, this hypothesis may suggest that many of Buzzacarini's readings could be dated back to the late 1470 s or early 1480 s, or even the 1490s; this is far from unlikely, but it may cause a minor discrepancy with the dating suggestions that may come from Merula and the Mela manuscript (see above). The main reason is that certain $\gamma \rho$ readings are written by Buzzacarini in what seems to be his earliest phase (black ink after erasure in the body of text), and then explained in marginal notes in a pale red ink which, in turn, is earlier than the darker red ink used for the Nicander quotation mentioned by Merula. ${ }^{31}$ Such is the case with Cat. 36.14, where Buzzacarini writes "Colchos", which he subsequently refers to in the note "Ibi Venus colebatur, ut alibi: "quequae regis Colchos queque Idalium frondosum"” (see Plate 6). Furthermore, this hypothesis leaves questions on the origin of Poliziano's $\gamma \rho$ readings unanswered.

b. Poliziano copied Buzzacarini's notes, or one of their descendants. This theory has the advantage of explaining the meaning of the $\gamma \rho$ symbol: it could be possible that Poliziano, perhaps during the afore-

${ }^{29}$ E. Bigi, "Ambrogini, Angelo", in Dizionario biografico degli Italiani, vol. 2 (Roma, 1960), 691-702.

30 On this episode see S. Pagliaroli, "Poliziano, Girolamo Avanzi, Catullo e Verona", Archivum Mentis 5 (2016), 67-90.

${ }^{31}$ Even though one can still argue that Merula does not explicitly say that Buzzacarini actually wrote that explanation, it could be possible that he wrote it down even years after informing Merula. 
mentioned visit to Verona, had the chance to collate Buzzacarini's manuscript - but in this case, one must imply at least one other source to justify the over twenty readings not found in Buzzacarini's manuscript. It could be possible, of course, that Poliziano conjectured them, but this would make the $\gamma \rho$ symbol harder to justify: for this reason, it could be more likely that he collated them from several sources. Another option is that Poliziano had access to a sort of apograph of Buzzacarini's manuscript with further conjectures (or readings), but such an apograph would need to have been written by an extremely careful scribe, as many of Buzzacarini's notes are indeed very hard to read or identify among other variants, such as 3.16 "pró miselle passer" (see Plate 7).

c. Both Poliziano and Buzzacarini shared a similar source. For this purpose, it is here worth remembering that many of the $\gamma \rho$ variants, which are not listed in Catullus Online as part of Poliziano's notes, are ascribed by Dániel Kiss to other printed editions by Giovanni Calfurnio (1481), Girolamo Avanzi, both in his Emendationes (1495) and in the first Aldine edition (1502), and even Alessandro Guarini (1521). ${ }^{32}$ All these scholars, as well as Buzzacarini, were based in the areas of Verona, Padua, Venice: it is possible, then, that Poliziano had the chance to collate these variant readings in the same cultural environment.

In each of the aforementioned scenarios it could even be possible that Poliziano actually met Buzzacarini and worked with him, as was probably the case with Pietro Bembo and the collation of Terence. ${ }^{33}$ Even though there is no evidence of their mutual acquaintance even in Giorgio Merula's pamphlet, it is worth reiterating that Buzzacarini was quite well-known among the other humanists: he was one of the recipients of Ermolao Barbaro's epistles, and he was also mentioned in two more letters, one to Giorgio Merula and the other to Pontico Faccino, in which Barbaro describes a conversation with Buzzacarini that eventually led to a conjecture for Suet. Nero 30.3. ${ }^{34}$

32 Hieronymi Avancii Emendationes in Catullum et Priapea (Venezia, Johannes Tacuinus de Tridino \& Innocens Ziletus, 1495 [USTC 997366]); Catullus. Tibullus. Propertius, Venezia, Aldo Manuzio, 1502 [USTC 821181]); Alexandri Guarini Ferrariensis In C.V. Catullum Veronensem per Baptistam patrem emendatum expositiones cum indice (Venezia, Giorgio Rusconi, 1521 [USTC 834877]).

${ }^{33}$ See Ribuoli 1981 (as in n. 2) 20, 81.

${ }^{34}$ V. Branca (ed.), Ermolao Barbaro, Epistolae, orationes et carmina, vol. 2 (Firenze, 1943), 43, 50, 68. Buzzacarini is also mentioned in Palladio's commentary on Catullus at Cat. 64.178: Catulli una cum commentariis eruditi viri Palladii Fusci Patavini (Venezia, Johannes Tacuinus de Tridino, 1496 [USTC 996172]). 


\section{Appendix \\ Poliziano's $\gamma \rho$ variants on Catullus}

$\dagger$ marks the readings apparently "dubious" for Poliziano.

* marks the variant readings shared with Buzzacarini.

The readings accepted by modern scholars are italicized.

A square bracket followed by three dots marks the sections cropped by a later bookbinder. Other hard to read passages are explicitly commented upon between round brackets.

\section{9 quod o patroa $\uparrow *$}

2.7 ut

2b.1 gratus mihi (Buzzacarini deletes "sit" and writes "gratum mihi")

3.16 proh miselle passer * (Buzzacarini: "pró”)

4.2 ait

4.3 impetum trabis * (trabis impetum?)

4.4 nequisse *

4.6 hadriatici *

4.20 utcunque

$6.12 \mathrm{mi}$... tacere * (as in "nam mi praevalet ista nil tacere")

8.9 tuque impote non es *

9.2 antistans $*$

10.8 quantum *

10.9 mihi (Buzzacarini writes "mihi" as part of an explanatory note: "scilicet "profuisse mihi"")

10.13 faceret $*$

10.15 aere *

10.27 inquio *

17.3 sub his totus irredivivus (Buzzacarini writes "sub his totus in redivivis", but in a note he adds "irredivivus: non renovatus ex vetusto" followed by "redivivus enim ex vetusto renovatus", which echoes Fest. 334, 1. 25 Lindsay)

17.6 vel saliaribus sacra pi [...* (another graphetai symbol is traced above "suscipiant" in the printed text, which is the reading witnessed by the vast majority of the manuscript tradition since the three oldest manuscripts, $\mathbf{O}, \mathbf{G}$, and $\mathbf{R}$. It could be a sign of collation, but in that case it would be the only occurrence in the whole incunable; another explanation could be that Poliziano began to write his graphetai note right 
above "suscipiant", but eventually decided to move it further from the text due to a lack of space, as the margin was already filled with two notabilia - see Plate 4).

17.14 cui cum sit $*$

22.14 infaceri est et infacetior rure ("infaceri" is hard to read due to the small handwriting. Buzzacarini writes "infaceto est et infacetior rure").

25.12 minuta * (reading uncertain due to small handwriting and faded ink, perhaps "minutia")

28.9 o memmi *

29.8 dioneus

30.7 me quoque (Buzzacarini writes "mi quoque")

35.13 inchoatam (Buzzacarini writes "incohatam")

35.18 invocata *

36.14 colchos *

41.1 at ne avara

44.7 alieno quo (reading uncertain due to small handwriting and faded ink)

53.5 salaputium

61.151 fine quae sine servit * "servit" is hard to read due to small handwriting and faded ink, perhaps "serviat": Buzzacarini writes "fine quae sine serviat")

61.189 at virum iuvenem tamen *

63.5 testes

63.14 velut exilii loca (Buzzacarini apparently writes "exulii", but another note above the line makes the reading quite difficult)

63.27 nova *

63.47 aestuanter usus

63.78 age corrupit face $[\ldots$

64.18 iam crurum *

64.25 tedis *

64.119 lecto *

64.119 ingrato fleret *

64.120 preoptaret (Buzzacarini writes "praeoptarit")

64.138 miserescere

64.183 lentos *

64.287 annosum $* \dagger$

63.324 columen peleu *

64.368 madefies * 
66.57 zephyritis *

66.59 scilicet ut *

66.94 fulgere $\mathrm{o}[\ldots \dagger$ (the reading is uncertain due to small handwriting)

67.32 comea *

68.46 charta

68.91 queque enim heu

68.128 quantum $\uparrow$

68.139 flagravit *

68.158 nobis

69.3 illam rarae $\dagger *$

71.1 sicui iure bono sacra $\uparrow[\ldots *$

77.3 meaque *

$77.4 \mathrm{sic}$ (the reading is uncertain due to small handwriting)

78b.4 fama loquetur a [... * (Buzzacarini writes "fama loquetur anus")

79.4 : amatorum $\dagger *$ (the reading is uncertain due to small handwriting)

80.8 illic te mulso labra notare fero $\dagger^{*}$

93.2 albus an ater homo *

94.1 mens tua $\dagger$

95.9 sodalis *

101.7 hae (the reading is uncertain due to faded ink and small handwriting)

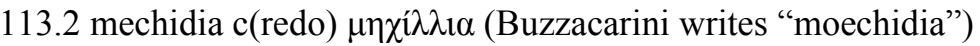

116.1 veniam dare queres (Buzzacarini writes "veniam dare quaeris")

116.4 icere $\mathrm{mi}$

Università degli Studi di Parma giovanni.grandi@studenti.unipr.it 
- Onfule pompeio primum duo cinna folebãt:

Mecilia faeto confule nunc iterum.

Manferunt duo:fed creuerunt milia in unum:

Singula foecundum femen adulterio,

De Salio Firmano.

f Irmanus falius non falfo mentula diues

Fertur:qui quot res in fe bab\& egregias

Aucupium omne genus pilcis prata arua ferafog

Nequicğ fructus fumptibus exuperat:

Quare contendo fit diues dum omnia defint

Soleom lardamiro dirmma d a : $r$

Plate 1: Roma, Biblioteca dell'Accademia Nazionale dei Lincei e Corsiniana, inc. 50.F.37, f. 37r.

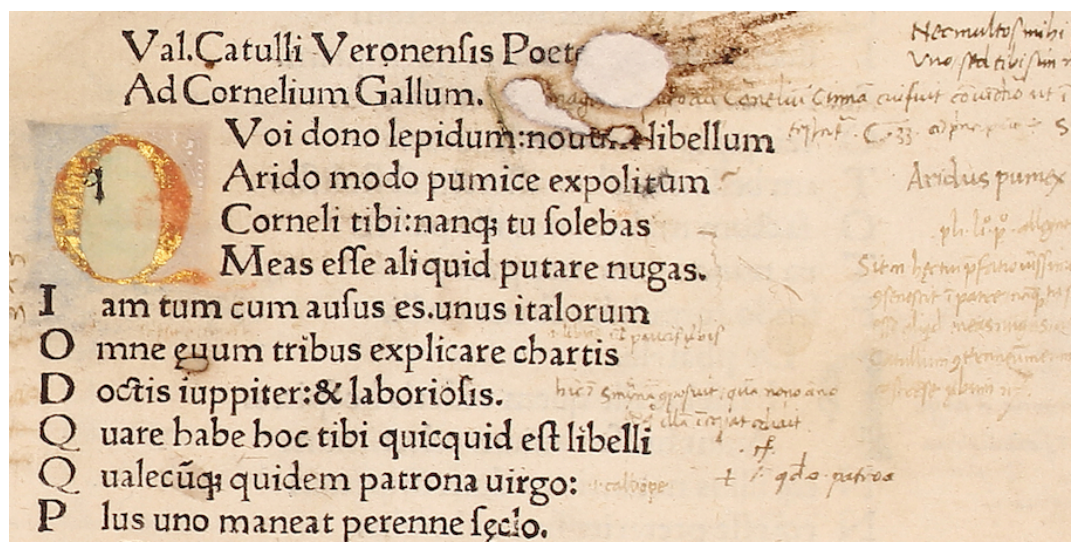

Plate 2: Roma, Biblioteca dell'Accademia Nazionale dei Lincei e Corsiniana, inc. 50.F.37, f. 4 r. 


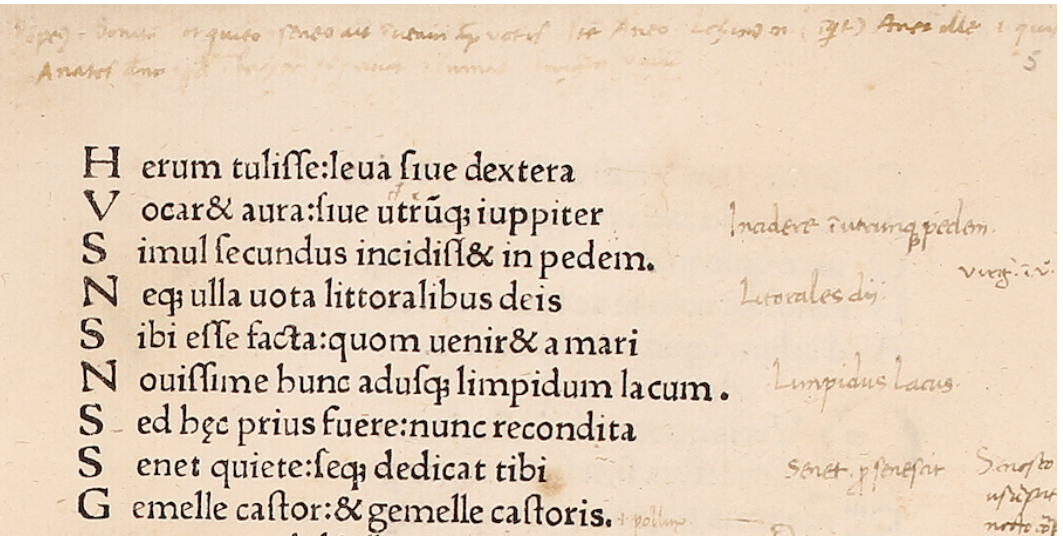

Plate 3: Roma, Biblioteca dell'Accademia Nazionale dei Lincei e Corsiniana, inc. 50.F.37, f. 5 r.

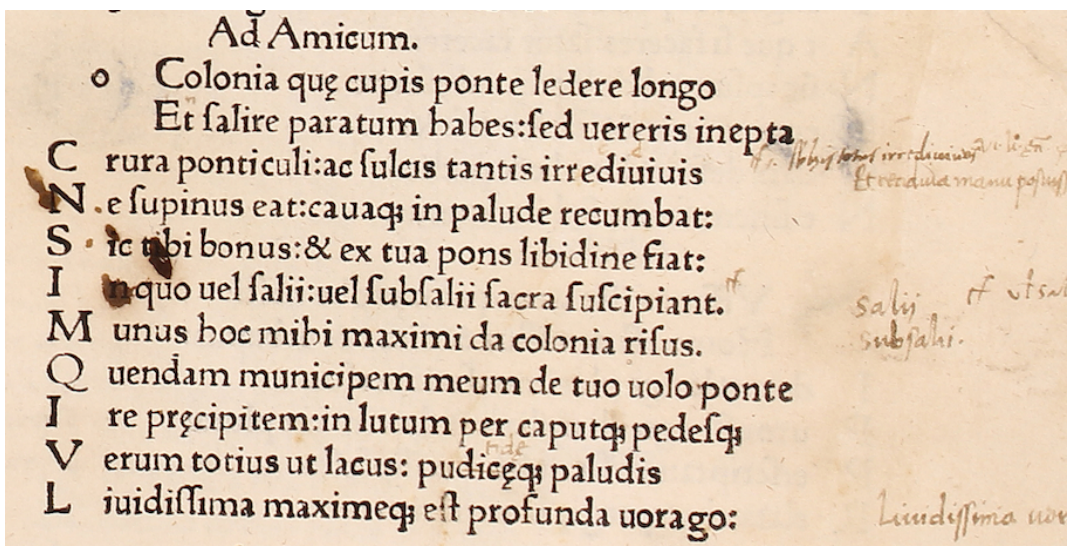

Plate 4: Roma, Biblioteca dell'Accademia Nazionale dei Lincei e Corsiniana, inc. 50.F.37, f. 8 r. 
$S$ ed potus targus ẹffuce mvneribus. $S$ idera cuk uterent, vina coma reora flam Proximvshydrochor fulgez $\&$ o arion procyon orecron

\section{AD IAN VAM}

Dula rocunda viro rocunda pazena

Plate 5: Venezia, Biblioteca Nazionale Marciana, ms. Lat. XII 153 (4453), f. 101r.

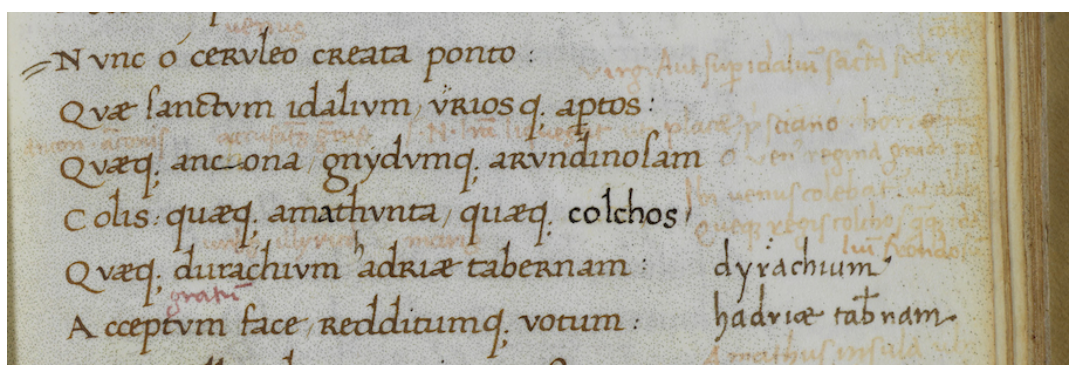

Plate 6: Venezia, Biblioteca Nazionale Marciana, ms. Lat. XII 153 (4453), f. 70r.

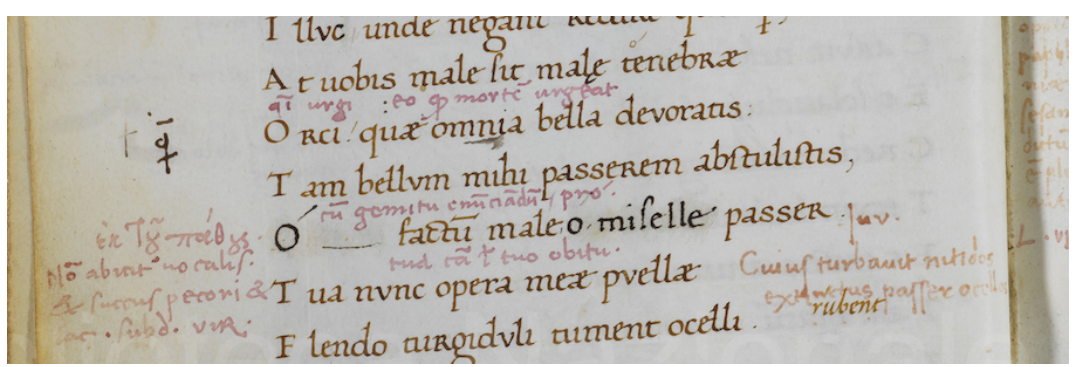

Plate 7: Venezia, Biblioteca Nazionale Marciana, ms. Lat. XII 153 (4453), f. 56v.

Plates 5-7: Su concessione del Ministero per i beni e le attività culturali Biblioteca Nazionale Marciana. Divieto di riproduzione. 